\title{
A non-starch-fermenting variant of Corynebacterium ulcerans
}

\author{
W. H. H. JEBB AND T. D. M. MARTIN \\ From the Public Health Laboratory, Radcliffe Infirmary, Oxford, and \\ the Department of Pathology, Royal Berkshire Hospital, Reading, Berks
}

SYNOPSIS Recently a non-starch-fermenting strain of $C$. ulcerans was isolated and a strain which did not hydrolyse urea when first isolated has also been discovered. For full identification of $C$. ulcerans both intradermal and subcutaneous tests in guinea-pigs are required, and it is recommended that these tests should be carried out with all organisms which culturally and morphologically resemble diphtheria bacilli.

Corynebacterium ulcerans was originally described by Gilbert and Stewart in 1927. Later investigations by Barratt (1933), Jebb (1948), Saxholm (1951), and Cook and Jebb (1952) have provided further tests to distinguish $C$. ulcerans from other pathogenic corynebacteria.

Wilson and Miles (1964) state that $C$. ulcerans produces acid in glucose, maltose, starch, dextrin, and trehalose (slowly), that it liquefies gelatin, hydrolyses urea, and fails to reduce nitrate. Most strains form two toxins, one immunologically identical with diphtheria toxin and one related to the toxin of $C$. ovis. Intradermal injection into guinea-pigs produces a purulent necrotic lesion that is not prevented by diphtheria antitoxin.

Recently, one of us (T.D.M.M.) isolated a nonstarch-fermenting variant of $C$. ulcerans from the throat of a schoolboy with a sore throat, of which this organism was considered to be the cause. The boy had been immunized against diphtheria. Apart from its failure to ferment starch this strain produced the typical reactions of $C$. ulcerans. On intradermal inoculation it produced ulcerating lesions within two days in two guinea-pigs which had received 20 units and 1,000 units respectively of diphtheria antitoxin. On subcutaneous inoculation, a guinea-pig protected by 500 units of diphtheria antitoxin, remained alive and apparently well for the 15 days it was kept under observation. An unprotected guinea-pig died in less than 48 hours. At necropsy there was a gelatinous oedema at the site of inoculation, free fluid in the peritoneal cavity, and the suprarenals were enlarged and haemorrhagic.

Received for publication 23 June 1965.

\section{DISCUSSION}

From a clinical standpoint, the most important thing to do with any organism which culturally and morphologically resembles $C$. diphtheriae is to determine whether or not it produces diphtheria toxin. This can be done both with $C$. diphtheriae and $C$. ulcerans by subcutaneous inoculation into protected and unprotected guinea-pigs or by the use of an Elek plate (Elek, 1948; Elek, 1949; Jameson, 1965). Like $C$. diphtheriae, not all strains of $C$. ulcerans produce a toxin which can be neutralized by diphtheria antitoxin (Petrie and McClean, 1934).

For full identification of strains of $C$. ulcerans, however, further tests are required. Cook and Jebb (1952) recommended that all organisms which, on primary isolation, colonially and morphologically appeared to be diphtheria bacilli should be tested for urea hydrolysis, nitrate reduction, haemolysis, and fermentation of glucose, maltose, sucrose, and starch. The use of a blood agar plate, to which a nitrate strip is added after inoculation (Cook, 1950), provides a rapid method of testing for nitrate reduction. Cook and Jebb also recommended that starch-fermenting strains which hydrolyse urea should always be further tested by intradermal inoculation into protected and unprotected guineapigs and possibly also by testing for gelatin liquefaction and trehalose fermentation.

The results that will be found on intradermal and subcutaneous inoculation of guinea-pigs with virulent and avirulent strains of $C$. diphtheriae and with strains of $C$. ulcerans which produce diphtheria 
TABLE I

\begin{tabular}{|c|c|c|c|c|}
\hline \multirow[b]{2}{*}{ Organism } & \multicolumn{2}{|l|}{ Subcutaneous Inoculation } & \multicolumn{2}{|l|}{ Intradermal Inoculation } \\
\hline & No Diphtheria Antitoxin & $\begin{array}{l}500 \text { Units of Diphtheria } \\
\text { Antitoxin }\end{array}$ & $\begin{array}{l}20 \text { Units of Diphtheria } \\
\text { Antitoxin }\end{array}$ & $\begin{array}{l}\text { 1,000 Units of Diphtheria } \\
\text { Antitoxin }\end{array}$ \\
\hline C. diphtheriae (virulent) & $\begin{array}{l}\text { Death in 1-4 days with } \\
\text { enlarged and haemor- } \\
\text { rhagic suprarenals }\end{array}$ & Remains alive & $\begin{array}{l}\text { Localized erythematous } \\
\text { lesion followed by } \\
\text { necrosis }\end{array}$ & No lesion \\
\hline $\begin{array}{l}\text { C. diphtherias (virulent) } \\
\text { C. ulcerans (which produces } \\
\text { diphtheria toxin) }\end{array}$ & $\begin{array}{l}\text { Remains alive } \\
\text { Death in } 1-4 \text { days with } \\
\text { enlarged and haemor- } \\
\text { rhagic suprarenals }\end{array}$ & $\begin{array}{l}\text { Remains alive } \\
\text { Remains alive }^{1}\end{array}$ & $\begin{array}{l}\text { No lesion } \\
\text { Large ulcerating lesion }\end{array}$ & $\begin{array}{l}\text { No lesion } \\
\text { Large ulcerating lesion }\end{array}$ \\
\hline $\begin{array}{l}\text { C. ulcerans (which does not } \\
\text { produce diphtheria toxin) }\end{array}$ & Remains alive $^{1}$ & Remains alive ${ }^{1}$ & Large ulcerating lesion & Large ulcerating lesion \\
\hline
\end{tabular}

${ }^{1}$ Occasionally these animals die; if they do the post-mortem appearances resemble those of infection with $C$. ovis (Barratt, 1933; Petrie and $\bigcirc$ McClean, 1934). The suprarenals are not affected.

toxin and those which do not are set out in Table I. Since a non-starch-fermenting strain of $C$. ulcerans has now been isolated and Shore (1964) has isolated a strain which did not hydrolyse urea when it was first isolated, it seems advisable to carry out guineapig inoculations by both intradermal and the subcutaneous routes with all strains of organisms which culturally and morphologically resemble diphtheria bacilli.

Of the other methods of distinguishing between $C$. diphtheriae and $C$. ulcerans, gelatin liquefaction and trehalose fermentation may both take a week or more, and failure to reduce nitrate is not a wholly reliable differential test, since occasional strains of C. diphtheriae also fail to reduce nitrate (Jebb, 1948).

We are grateful to Dr. C. A. Martin of Swallowfield, Berks, for supplying details of the patient from whom the organism was isolated, and to Dr. E. C. Armstrong of the Public Health Laboratory, Liverpool, and Dr. J. H. Y Shore, of Southlands Hospital, Shoreham-by-Sea, for 음 information about the urease-negative strain mentioned.

\section{REFERENCES}

Barratt, M. M. (1933). J. Path. Bact., 36, 369.

Cook, G. T. (1950). J. clin. Path., 3, 359.

- and Jebb, W. H. H. (1952). Ibid., 5, 161.

Elek, S. D. (1948). Brit. med. J., 1, 493.

- (1949). J clin. Path., 2, 250.

Gilbert, R., and Stewart, F. C. (1927). J. Lab. clin. Med., 12, 756

Jameson, J. E. (1965). Mth. Bull. Min. Hlth Lab. Serv., 24, 55.

Jebb, W. H. H. (1948). J. Path. Bact., 60, 403.

Petrie, G. F., and McClean, D. (1934). Ibid., 39, 635.

Saxholm, R. (1951). Ibid., 63, 303.

Shore, J. H. (1964). Personal communication.

Wilson, G. S., and Miles, A. A. (1964). Topley \& Wilson's Principles of Bacteriology and Immunity, 5th ed., p. 605. Edward Arnold, London. 